Studying Online: Student Motivations and Experiences in ALA-Accredited LIS Programs

By: Fatih Oguz, Clara M. Chu and Anthony S. Chow

Oguz, F., Chu, C. M., \& Chow, A. (2015). Studying online: Student motivations and experiences in ALA-accredited LIS programs. Journal of Education for Library and Information Science, 56(3), 213-231.

Made available courtesy of Association for Library and Information Science Education: http://dpi-journals.com/index.php/JELIS.

***@ Association for Library and Information Science Education. Reprinted with permission. No further reproduction is authorized without written permission from Association for Library and Information Science Education. This version of the document is not the version of record. Figures and/or pictures may be missing from this format of the document. $* * *$

\begin{abstract}
:
This paper presents a large scale study of online MLIS students ( $\mathrm{n}=910)$, who completed at least one online course and were enrolled in 36 of the 58 ALAaccredited MLIS programs in Canada and the United States. The results indicate that the typical student is female, White, lives in an urban setting, and is in her mid-30s. Online students were found to be quite diverse, with statistically significant differences in their preferences and satisfaction across five demographic variables: age (generational cohort), employment status, urban status, commute distance, and program modality. Three motivations emerged: accommodation, predisposition, and selectivity, which influenced the respondents to choose online learning. The prevalent issues online MLIS students experienced were a sense of isolation from peers and instructors, and a lack of professional development and networking opportunities with peers. The findings have implications for enhancing MLIS online education including marketing, course offerings, and student support services.
\end{abstract}

Keywords: online courses | distance education | student characteristics | rural/urban status | commute distance | student satisfaction | student motivations

Article:

***Note: Full text of article below 


\title{
Studying Online: Student Motivations and Experiences in ALA-Accredited LIS Programs
}

\author{
Fatih Oguz \\ Department of Library and Information Studies, The University of North Carolina at \\ Greensboro.Email:f oguz@uncg.edu
}

Clara M. Chu

Mortenson Center for International Library Programs, University of Illinois at Urbana-

Champaign.Email: cmchu@illinois.edu

\section{Anthony S. Chow}

Department of Library and Information Studies, The University of North Carolina at

Greensboro.Email: aschow@uncg.edu

\begin{abstract}
This paper presents a large scale study of online MLIS students $(\mathrm{n}=910)$, who completed at least one online course and were enrolled in 36 of the 58 ALAaccredited MLIS programs in Canada and the United States. The results indicate that the typical student is female, White, lives in an urban setting, and is in her mid-30s. Online students were found to be quite diverse, with statistically significant differences in their preferences and satisfaction across five demographic variables: age (generational cohort), employment status, urban status, commute distance, and program modality. Three motivations emerged: accommodation, predisposition, and selectivity, which influenced the respondents to choose online learning. The prevalent issues online MLIS students experienced were a sense of isolation from peers and instructors, and a lack of professional development and networking opportunities with peers. The findings have implications for enhancing MLIS online education including marketing, course offerings, and student support services.
\end{abstract}

Keywords: online courses, distance education, student characteristics, rural/urban status, commute distance, student satisfaction, student motivations

\section{Acknowledgements}

The authors thank Graduate Assistant Mimi Smith-DeCoster for her research assistance and data collection. 
While online education has grown at a fast pace in the United States, this trend is also evident across the globe at institutions of higher education ("8 countries", 2012). Due to the evolution of open education through the offering of massive open online courses (MOOCs), anyone around the globe with an internet connection is able to freely access MOOCs (Yuan \& Powell, 2013). This phenomenon in global distance learning (Hanover Research, 2011) is showing that e-learning is the fastest growing market in education which by 2017 is expected to increase by $23 \%$ (IBIS Capital, 2013).

In the United States online education has grown at a much greater pace than has overall college enrollment. In fall 2008, over 600,000 graduate students took at least one online course, which constitutes about $14 \%$ of all students who took at least one online course in postsecondary degree-granting institutions in the United States (Allen \& Seaman, 2010). Likewise, the American Library Association (ALA)-accredited master's programs are seeing continuing changes in their enrollment as more students choose to take a hybrid of traditional face-toface and online courses or an entirely online degree. In library and information science (LIS) programs, online course offerings have also been steadily increasing as about $76 \%$ of all distance LIS courses $(n=2,039)^{1}$ during the $2009-2010$ academic year were delivered online (Wallace \& Naidoo, 2010b). ${ }^{2}$

\footnotetext{
${ }^{1}$ The ALISE statistical report compiles data for distance courses, in which different delivery methods are reported, including online.

${ }^{2}$ Information needed to update this data was missing from the most recently available ALISE statistical report. Data for "number of courses" which should appear in Table III-30a Method of
} 
Convenience, flexibility, and affordability are potential factors that allow students to consider and choose online education to pursue a master's degree in library and information science (MLIS). In the context of this study, the acronym MLIS refers to the various graduate degree names in the library and information field. In order for MLIS programs to effectively meet the needs of their online students, it is important to understand these students and their experiences. This study explored a number of issues to better understand online MLIS students. Who is a typical online MLIS student? Are they older? Employed? Why did they choose to pursue their education online? What are the factors that influence their satisfaction with an online education? Are there differences based on demographic factors?

\section{Literature Review}

The primary rationale for program delivery of online courses in LIS include increasing access to professional qualifications, removing geographical barriers, and offering independent and more diverse lifestyle oriented courses and learning opportunities (Islam, Kunifuji, Hayama, \& Miura, 2011). Students' motivations for taking online classes vary. For some, work or family commitments, scheduling conflicts, or physical distance from the campus may be a determining factor. Positive prior experiences with online education, ability to study at their own pace, broader selection of courses in online format, quality of

Course Delivery (this title appeared in the Table of Contents) of the ALISE Statistical Report 2012 was not included. 
the program, potential savings of time and money on travel, and cost of education also appeal to students. It is well established that these benefits afforded by online education are crucial for students when making a decision to enroll in online courses (Dutton, Dutton, \& Perry, 2002; Pastore \& Carr-Chellman, 2009). External factors including feedback from peers or instructors, and unavailability of classes in face-to-face format may also be motivating factors for students (Pastore \& Carr-Chellman, 2009; Scott, 2011).

Information and communication technologies have extended the reach of LIS education, which has included blended, TV, Telenet, video conferencing, and online delivery (Barron, 1996). Despite the growing body of research addressing distance education in LIS programs, larger studies are needed to understand factors that motivate students to take online classes and challenges that they encounter when taking online classes.

An online course can be defined as a Web-based instructional method in which at least $80 \%$ of the instruction occurs via the Internet (Allen \& Seaman, 2007). LIS programs in the United States have been offering online classes since the 1990s (Small \& Paling, 2002). Online classes offered by a majority of ALAaccredited LIS programs have little to no face-to-face instruction (Bird, Chu, \& Oguz, 2011). The earliest statistics issued by the Association for Library and Information Science Education (ALISE) on online offerings in LIS programs are available from the 2000-2001 academic year in which about 14\% (n=994) of course offerings were online, while over ten years later (2011-2012 academic year) almost $60 \%$ of the courses were delivered online as shown in Figure 1. 


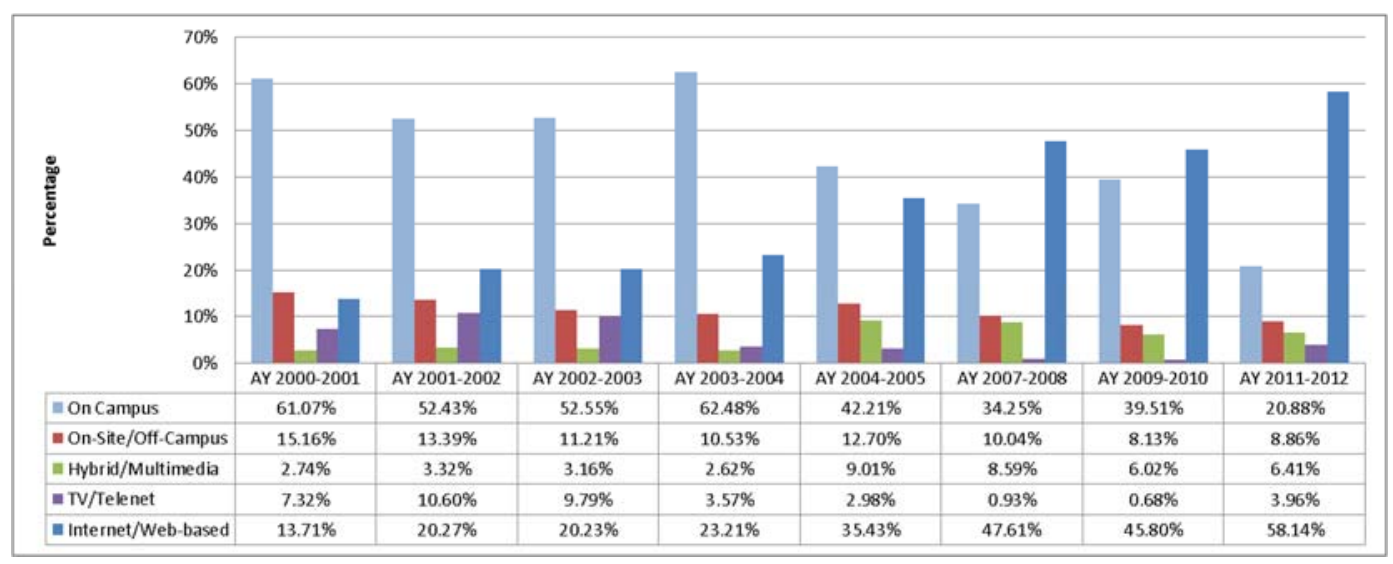

Figure 1 - Course Delivery Modality in LIS (Academic Year 2000 - 2011). Data for Course Delivery Modalities from Daniel and Saye (2002, 2003, 2005), Saye (2008), Saye and Wallace (2009), Wallace and Naidoo (2010a, 2010b), and Wallace (2012).

Research has found that online courses are not only for the non-traditional student who often has work or family responsibilities that limit the student's ability to attend classes in traditional face-to-face format, but also for the residential student (Pastore \& Carr-Chellman, 2009). The non-traditional student is someone who is not a full-time student, straight out of high school, while the residential student is a student who generally takes their courses on campus.

It has also found that one of the most important motivations for students to enroll in an online course is convenience. Research has shown a number of attributes of convenience, which include not need needing to relocate and ease of access to content at any time (see Table 1).

Table 1 - Attributes of Convenience and Flexibility in Online Education Research 
1. ability to complete the course requirements in a setting of the student's choice

2. not needing to relocate

3. ability to keep current employment

4. ease of access to course content at any time

5. set own schedule and not needing to travel to campus for instructional purposes
1. Mellon \& Kester, 2004; Pastore \& CarrChellman, 2009.

2. Mellon \& Kester, 2004; Wilde \& Epperson, 2006; Wyatt, 2005.

3. Pastore \& Carr-Chellman, 2009; Small \& Paling, 2002; Wilde \& Epperson, 2006.

4. Dutton et al., 2002; Mellon \& Kester, 2004; Pastore \& Carr-Chellman, 2009; Small \& Paling, 2002.

5. Dutton et al., 2002; Dyrbye, Cumyn, Day, \& Heflin, 2009; Fredericksen, Swan, Pelz, Pickett, \& Shea, 1999; Mellon \& Kester, 2004; Pastore \& Carr-Chellman, 2009; Small \& Paling, 2002; Wyatt, 2005.

6. Pastore \& Carr-Chellman, 2009; Wyatt, 2005.

Although residential students are increasingly enrolling in online courses, Wyatt (2005) and Dutton et al., (2002) found that geographical proximity is a very important motivation, especially for those who need to commute to campus. In some cases, students may be motivated by their curiosity of the online course format or the technology-intensive aspect of this modality (Dyrbye, Cumyn, Day, \& Heflin, 2009; Wilde \& Epperson, 2006). 
It has been shown that there are no significant differences between online and traditional course delivery modalities in terms of student achievement (Dutton et al., 2002; Means, Toyama, Murphy, Bakia, \& Jones, 2009) and students' perception of academic rigor (Mortagy \& Boghikian-Whitby, 2010; Pastore \& Carr-Chellman, 2009). Differences, however, between these modalities in other aspects such as satisfaction, learning, and interaction with their peers have been found. Tucker (2001) and Dutton et al. (2002) found that older students were more likely to prefer distance education because of reasons including family and work commitments. Fredericksen, Swan, Pelz, Pickett, and Shea (1999) reported that older students (36-45 age group) were more satisfied with online courses and learned the most online than younger students (16-25 age group). Students tend to perceive face-to-face classes as more engaging in terms of learning and interaction regardless of their course attendance mode (distance, face-to-face) (Hagel \& Shaw, 2006). Sher (2009) found that student-to-student and student-toinstructor interactions were significantly associated with student learning and satisfaction. These interactions can be related to- and may be impeded by- the student's sense of isolation from peers, instructor, and school; lack of technical and academic support; and limited opportunities for social interaction and professional development (Croft, Dalton, \& Grant, 2010; Hara \& Kling, 1999; Kazmer, 2007; Muilenburg \& Berge, 2005). Students' experiences with online classes are also informed by their motivations as older students have certain constraints including family and work commitments (Fredericksen et al., 1999; Tucker, 2001); such barriers, however, tend to be rated lower by older and male 
students (Muilenburg \& Berge, 2005). The students' age may in part explain younger students' dissatisfaction with online education as age may serve as an indicator for temporal proximity to more traditional face-to-face education experience (Kazmer, Gibson, \& Shannon, 2013).

The present study focused on graduate students' experiences with online education while completing their MLIS degree in an ALA-accredited institution. Although some LIS programs do not offer online courses, students from such programs were invited to participate in the study as they may have taken online LIS courses at another program for credit. The following research questions guided the study:

RQ1- What are the demographic characteristics of students pursuing an online MLIS education?

RQ2 - What factors influence students to select online MLIS coursework? RQ3 - What factors are associated with student satisfaction and an online MLIS degree?

RQ4 - What issues concern online MLIS students?

\section{Method}

The study used an online questionnaire (see Appendix A) to gather data from students enrolled in all ALA-accredited LIS programs, which are located in the United States, Puerto Rico, and Canada. At the time of the research there were 58 LIS programs accredited by the ALA ("Alphabetical List of Institutions", 2013). Because of the lack of a suitable sampling frame, a non-probability sampling method was employed. The questionnaire was administered by email in 
spring of 2012 with the assistance of the administration of the LIS programs and their student associations. Thirty-six programs from Canada and the United States were represented by the 1,038 students who participated in the study.

Respondents who had taken and completed at least one online course constituted the sample ( $\mathrm{n}=910)$ that was used for analysis and the reporting of the results. Although a non-probability sampling strategy was employed to collect the data, no statistically significant difference was detected between demographic characteristics of respondents in terms of age, gender, and ethnicity with that of current MLIS students, reported in the 2012 ALISE Statistical Report (Wallace, 2012), suggesting the study's participants reflected a representative sample.

\section{Data Instrument and Analysis}

An 18-item questionnaire was developed based on characteristics related to students' experiences in online courses. The questionnaire consisted of two major sections: demographic information, and experiences with online classes and programs. The statements used to determine students' motivations to enroll in an online class (RQ2) were adapted in part from Dutton et al. (2002), Scott (2011), and Wilde and Epperson (2006). The statements used to assess student satisfaction with programmatic services and their experiences while taking online classes were developed from a review of the research conducted by Dutton et al. (2002), Fredericksen et al., (1999), and Kazmer (2007).

Residential zip code information was collected in order to calculate commute distance of each participant from a program's main campus. The Google Maps application program interface (API) was used to calculate commute 
distance based on student-supplied zip code. Commute distance was calculated from the population centroid of the origin residential zip code area (student's zip code) to the population centroid of the destination zip code area (main campus zip code). Analysis of commute distance results revealed no outliers in the sample ( $\mathrm{n}=910)$. Student residential zip codes were mapped to Rural Urban Commuting Area codes ("Rural Urban Commuting," n.d.) to determine their rural/urban resident status while attending school. RUCA codes use measures of population density, urbanization, and daily commuting to classify the United States Census tracts. Responses from students $(\mathrm{n}=44)$ attending MLIS programs in Canada $(\mathrm{n}=4)$ were not assigned an urban status code, therefore excluded in certain analyses where urban status code was used.

Since the data in question did not show normalcy, non-parametric tests (Pearson Chi-Square, Kruskal Wallis, and Mann-Whitney U) were applied to determine significance of relationships among both scalar and categorical variables. The Cronbach's alpha $(\alpha)$ statistic was used to measure internal consistency reliability of statements used for students' motivations for taking online courses, and their experiences and satisfaction with online courses. The results were summarized using exploratory factor analysis, a statistical method for identifying groups of variables (Field, 2009).

\section{Results}

The results of the study allow us to answer each of the study's four major research questions. The data suggest a number of trends in demography, student considerations when choosing an entirely online program, satisfaction of such 
students with online education, and student experiences while taking online classes.

\section{What are the demographic characteristics of students pursuing an online}

\section{MLIS education?}

Although a non-probability sampling method was used to disseminate the survey, no statistically significant differences were detected for age, gender, and race between data used in this study and student data reported in the most recent ALISE Statistical Report (Wallace, 2012). The majority of survey participants were female (84.5\%), White $(87.5 \%)$, and lived in urban areas $(91.1 \%)$ (see Table 2). Almost half of the students (49\%) attending a partially or entirely online MLIS program were of Generation X, with the mean age being 34.3 (see Table 2).

Table 2 - Respondent Demographic Information

\begin{tabular}{ccc}
\hline & Frequency & Percentage \\
\hline Generational Cohort /Age* $(\mathrm{n}=909, \overline{\boldsymbol{x}}=34.3, \mathrm{SD}=9.8)$ & & \\
\hline Gen Y (under 29) & 345 & \\
\hline Gen X (29-47) & 445 & \\
\hline Baby Boomers (over 47) & 119 \\
\hline Gender (n=907) & & \\
\hline Male & 135 \\
\hline Female & 766 \\
\hline Other & 6 & 84.5 \\
\hline
\end{tabular}

Race / Ethnicity ( $\mathrm{n}=896)$

\begin{tabular}{lcc}
\hline White (Non-Hispanic) & 784 & 87.5 \\
\hline Black or African American & 30 & 3.3 \\
\hline Hispanic or Latino & 26 & 2.9 \\
\hline Multiracial & 26 & 2.9 \\
\hline Asian, Asian-American, or Pacific Islander & 23 & 2.6
\end{tabular}




\begin{tabular}{|c|c|c|}
\hline American Indian or Native Alaskan & 7 & 0.8 \\
\hline \multicolumn{3}{|l|}{ Employment Status (n=903) } \\
\hline Full-Time & 388 & 43 \\
\hline Part-Time & 365 & 40.4 \\
\hline Unemployed & 150 & 16.6 \\
\hline \multicolumn{3}{|l|}{ Metro Status** $(n=832)$} \\
\hline Urban & 758 & 91.1 \\
\hline Large Rural & 41 & 4.9 \\
\hline Small Rural & 24 & 2.9 \\
\hline Isolated & 9 & 1.1 \\
\hline \multicolumn{3}{|l|}{ Program Modality $(\mathrm{n}=910)$} \\
\hline Entirely Online & 409 & 44.9 \\
\hline Partially Online & 501 & 55.1 \\
\hline \multicolumn{3}{|l|}{ Commute Distance $^{*}(\mathrm{n}=886, \overline{\boldsymbol{x}}=270, \mathrm{SD}=592)$} \\
\hline $0-50$ miles & 499 & 56.3 \\
\hline $51-100$ miles & 85 & 9.6 \\
\hline $101-200$ miles & 98 & 11.1 \\
\hline $201-400$ miles & 68 & 7.7 \\
\hline$>400$ miles & 136 & 15.3 \\
\hline
\end{tabular}

* The data were originally collected or calculated as continuous data.

** Respondents from MLIS Programs in Canada were not included.

The majority of respondents who were taking online courses were employed (83\%), were attending a partially online program (55.1\%), or resided (56.3\%) within 50 miles commute distance from the main campus.

A statistically significant difference was detected in terms of age between entirely and partially online students $(\mathrm{U}=82567, \mathrm{p}<0.001)$. Students who were attending entirely online programs were significantly older $(\overline{\mathrm{x}}=36, \mathrm{SD}=10)$ than 
those $(\overline{\mathrm{x}}=33, \mathrm{SD}=9.5)$ who attended a partially online program $(\mathrm{p}<0.001)$. In terms of generational cohort differences, a large majority of younger Generation Y students were attending partially online programs as opposed to their older peers who attended an entirely online program $(\mathrm{p}<0.001)$.

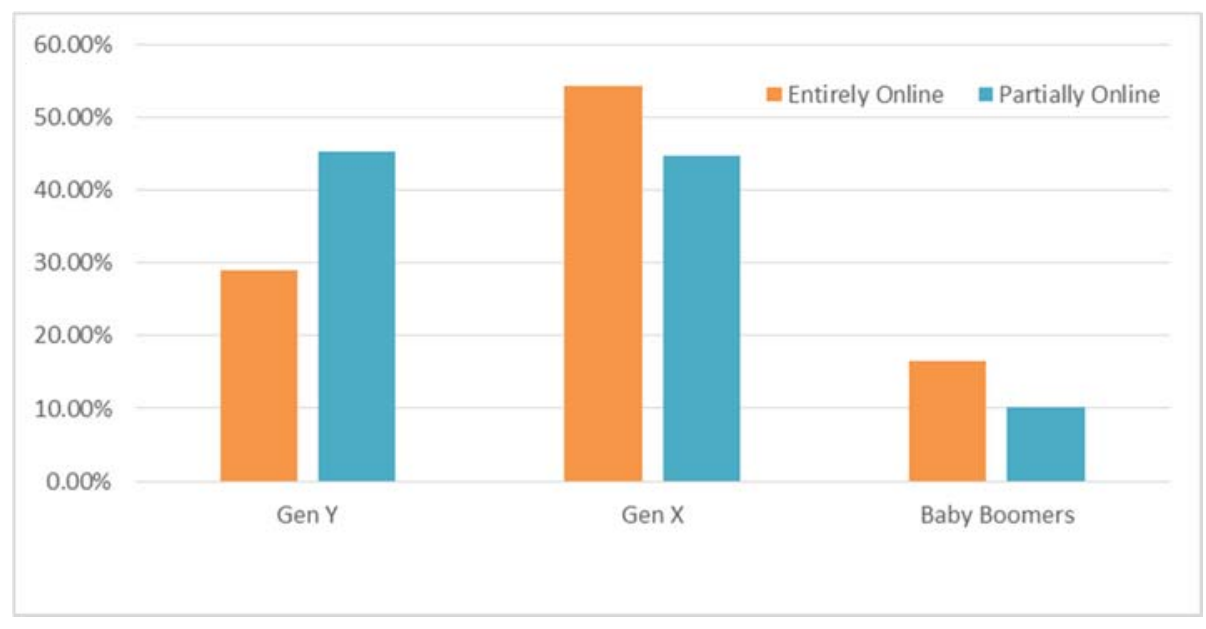

Figure 2 - Participation in Online Education by Generational Cohort $(n=909, p<0.001)$

The average commute distance of the respondents was 270 miles, however, entirely online students lived significantly $(\mathrm{p}<0.001)$ farther from main campus with an average distance of 463 miles $(\mathrm{SD}=748)$ than those who were in partially online programs ( $\overline{\mathrm{x}}=118$ miles, $\mathrm{SD}=364)$. Gen $\mathrm{Y}$ students tended to reside closer to campus ( $\overline{\mathrm{x}}=165$ miles) than Gen $\mathrm{X}(\overline{\mathrm{x}}=327$ miles) and Baby Boomers ( $\overline{\mathrm{x}}=367$ miles). A majority of students who had full-time employment were attending an entirely online program while a majority of students who had part-time employment were attending a partially online program $(\mathrm{p}<0.01)$.

In addition, a large portion of students who were unemployed at the time of data collection were attending an entirely online program. Although a large majority of respondents lived in urban areas, almost all of the partially online students $(96.7 \%)$ resided in an urban setting compared to $84.5 \%$ of entirely online 
students who resided in urban areas $(\mathrm{p}<0.001)$. Thirty-two (32) LIS programs from the United States that were represented in this study were located in urban areas as per RUCA codes.

Race/ethnicity data were reclassified as White and Non-White ${ }^{3}$ because of small sample sizes in categories other than White for statistical analysis purposes. Race/ethnicity, however, did not have a statistically significant association with generational cohort, employment status, urban status, commute distance, and program modality.

\section{What factors influence students to select online MLIS coursework?}

Student motivation for taking online coursework varied. Students enrolled in partially online programs have access to traditional and blended courses. In some cases, certain courses in such MLIS programs may be offered online-only, which in turn, limits the students' ability to choose an alternative delivery mode. Eleven statements were used to assess student motivation including availability, broader selection of courses online, past experience, personal circumstances (e.g., health), and conflict with work schedule. The Cronbach's alpha statistic was estimated as 0.69 indicating an acceptable level of internal consistency. The results of exploratory factor analysis identified three factors with an eigenvalue higher than one. These three factors explained $54.01 \%$ of the total variance in the students' choosing to take online coursework. In this analysis, the

\footnotetext{
${ }^{3}$ The use of the term Non-White is not to privilege identity based on a White majority but to try to use a referent that encapsulates the notion of ethno-racial minority, minority, people of color, etc. on which it is also difficult to reach a consensus.
} 
KMO measure was 0.808 , suggesting enough of a satisfactory factor analysis to proceed, and the Bartlett's test of sphericity being statistically significant $(\mathrm{p}<0.001)$. These results suggest that factor analysis was an appropriate technique for summarizing the data. Principal component factor analysis of student motivation ( $\mathrm{n}=489, \alpha=0.69)$ revealed three factors: accommodation, predisposition, and selectivity.

Accommodation refers to convenience and flexibility offered by online classes to allow the student to take classes or to create a schedule that fits the student's lifestyle and other priorities. This includes the flexibility to enroll in an online course when the student's ability to enroll in traditional courses was limited by certain responsibilities or concerns. Accommodation explained $24.1 \%$ of the variance in the students' choosing to take online coursework. Predisposition refers to the student's positive perception of online classes, reached on their own or from recommendations. Predisposition represents a more intentional motivation to enroll in an online course when there were no limiting issues for the student and explained $17.6 \%$ of the variance. Selectivity describes a student's choice/motivation to take online classes due to the limitation of the only available format for classes, or in contrast a broader selection of classes available online. This factor explained $12.3 \%$ of the variance.

To assess whether these motivations were related to demographic variables used in this study, the Kruskal-Wallis test was conducted. None of the motivations were found to be significantly associated with race/ethnicity. Accommodation was, however, found to have a statistically significant association 
with generational cohort as shown in Table 3. The Kruskal-Wallis test is an omnibus test statistic and does not indicate which specific groups are significantly different than each other; therefore pairwise comparisons were needed. Pairwise comparisons of generational cohort groups by accommodation indicated that the differences were significant between each pair of generational cohort. Accommodation as a motivation was statistically more important for older students than their younger peers $(\mathrm{p}<0.001)$.

Table 3 - Motivations for Taking Online Courses by Generational Cohort $(n=494)$

\begin{tabular}{lccc}
\hline & Generational Cohort & n & Mean Rank \\
\hline Accommodation* & Gen Y & 222 & 205.64 \\
& Gen X & 221 & 273.38 \\
& Baby Boomers & 51 & 317.61 \\
Predisposition & Gen Y & 222 & 258.94 \\
& Gen X & 221 & 236.50 \\
\hline Selectivity & Baby Boomers & 51 & 245.37 \\
\hline F $<0.001$ & Gen Y & 222 & 236.70 \\
& Gen X & 221 & 258.85 \\
& Baby Boomers & 51 & 245.33 \\
\hline
\end{tabular}

Statistically significant associations were also detected between students' employment status and motivations of accommodation $(\mathrm{p}<0.001)$ and predisposition $(\mathrm{p}<0.05)$ as shown in Table 4. Pairwise comparisons of employment statuses by these two motivations were conducted to investigate which pairs of employment status categories differed significantly. There was no significant difference in terms of importance of accommodation between students who had part-time employment and were unemployed. Accommodation, however, 
was significantly more important for those who had full-time employment than for those who have either part-time employment or were unemployed. There was no significant difference in terms of predisposition between students who had full-time and part-time employment. Moreover, predisposition was significantly less important for those who were unemployed than for those who had full- or part-time employment.

Table 4 - Motivations for Taking Online Courses by Employment Status $(n=486)$

\begin{tabular}{llll}
\hline & Employment Status & n & Mean Rank \\
\hline Accommodation* & Full Time & 185 & 305.48 \\
& Part Time & 233 & 202.03 \\
& Unemployed & 68 & 216.96 \\
\hline Predisposition** & Full Time & 185 & 255.95 \\
& Part Time & 233 & 244.28 \\
& Unemployed & 68 & 206.95 \\
\hline Selectivity & Full Time & 185 & 238.26 \\
& Part Time & 233 & 242.35 \\
\hline p $<0.001 * * \mathrm{p}<0.05$ & Unemployed & 68 & 261.70 \\
\hline
\end{tabular}

A statistically significant association was found between students' metro status and accommodation as motivation $(\mathrm{p}<0.05)$. Pairwise comparisons suggested that accommodation was significantly more important for students who were residing in large rural areas than those from urban areas. There was also a statistically significant association between commuting distance (as groups) and accommodation as a motivation $(\mathrm{p}<0.01)$. Pairwise comparisons indicated that accommodation was significantly less important for those who resided within 50mile radius of campus and those who lived farther from 50 miles. 


\section{What factors are associated with student satisfaction and an online MLIS degree?}

About half of the participants reported studying in an entirely online program ( $\mathrm{n}=409$ or $44.9 \%)$. Of these, 396 reported that they chose an entirely online program because of not needing to relocate $(90 \%)$, the quality of education (89.1\%), the ability to keep current employment (81.6\%), the cost of education (77.5\%), and the lack of access to a close-by, on-site (face-to-face) MLIS program $(53.8 \%)$.

Participants were asked to respond to eight statements about availability of certain services at the institution or program levels including academic advising, mentoring, and placement services to assess entirely online MLIS students' satisfaction. Overall, students were satisfied with all services with the highest satisfaction being with virtual practica, online lectures, and professional development opportunities as shown in figure below. The results of exploratory factor analysis identified one factor with an eigenvalue higher than 1 . The total variance explained was $53.37 \%(\mathrm{KMO}=0.862, \mathrm{p}<0.001, \alpha=0.87, \mathrm{n}=237)$. The estimated factor score of the new variable was used to capture students' satisfaction with availability of certain services at the institution or program levels. A new binary variable was created by assigning 0 to students with negative factor scores (dissatisfied), and 1 to students with positive factor scores (satisfied) in order to investigate students' satisfaction in terms of demographic variables. There were no statistically significant differences in terms of satisfaction between White and Non-White students. Although a larger percentage of older students 
(Gen X and Baby Boomers) appeared to be more satisfied than their younger peers (Gen Y) in entirely online MLIS programs, entirely online MLIS students' satisfaction with the availability of certain services in the program was not associated with demographic variables including employment status, metro status (e.g., urban, rural), and commute distance.

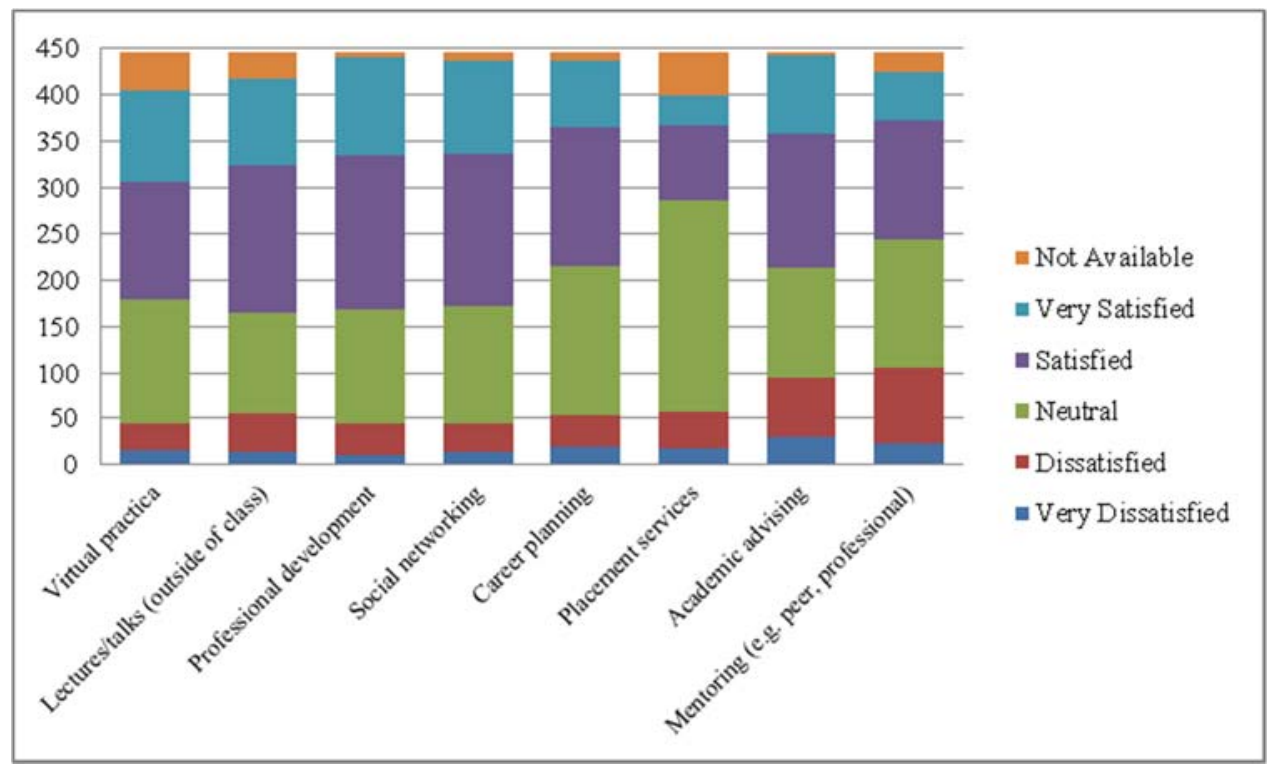

Figure 3 - Online Student Satisfaction $(n=447)$

\section{What issues concern online MLIS students?}

The most prevalent concerns reported by online MLIS students are: 1) a sense of isolation from peers, 2) a sense of isolation from instructors, 3) lack of professional development opportunities, and 4) lack of networking opportunities with peers. Students felt well-supported in terms of technical and academic support.

The results of exploratory factor analysis identified one factor with an eigenvalue higher than 1 , and the total variance explained was $58.35 \%(\mathrm{KMO}=$ 0.827, $\mathrm{p}<0.001, \alpha=0.87, \mathrm{n}=891)$. The estimated factor score of the new variable 
was used to capture students' experience with online education. A new binary variable was created by assigning 0 to students with negative factor scores (negative experience), and 1 to students with positive factor scores (positive experience) for further analyses.

Race/ethnicity was not found to be significantly associated with students' experiences with online education. A statistically significant difference, however, was found between age and students' experience $(U=89784.5, p<0.05)$. In terms of generational cohort differences, younger Gen Y students had more negative perceptions of experience with online education compared to their older peers who had more positive experience with online education $(\mathrm{p}<0.05)$. Those who had full-time employment had also more positive experience compared to those who had part-time employment and the difference was statistically significant $(\mathrm{p}<0.01)$ as shown in Table 5 .

Table 5 - Experience with Online Education by Employment Status $(n=885, p<0.01)$

\begin{tabular}{lrlrl} 
& \multicolumn{3}{c|}{ Employment Status } & \\
\cline { 2 - 4 } & Full-Time & Part-Time & Unemployed & Total \\
\hline Positive Experience & $47.6 \%(219)$ & $35.0 \%(161)$ & $17.4 \%(80)$ & $100.0 \%(460)$ \\
Negative Experience & $37.9 \%(161)$ & $46.4 \%(197)$ & $15.8 \%(67)$ & $100.0 \%(425)$
\end{tabular}

As noted earlier, a large majority of students lived in urban areas. However, those who lived in non-urban areas were found to have a more positive experience $(\mathrm{p}<0.05)$ with online education. Similarly, those who lived farther from campus had a more positive experience with online education than those who lived closer as shown in Table 6.

Table 6 - Experience with Online Education by Commute Distance $(n=868, p<0.05)$ 


\begin{tabular}{lcccccc} 
& \multicolumn{5}{c|}{ Commute Distance (in miles) } & Total \\
\cline { 2 - 6 } & $<\mathbf{5 0}$ & $\mathbf{5 1 - 1 0 0}$ & $\mathbf{1 0 1 - 2 0 0}$ & $\mathbf{2 0 1 - 4 0 0}$ & $>\mathbf{4 0 0}$ \\
Positive Experience & $47.5 \%(230)$ & $53.6 \%(45)$ & $53.1 \%(52)$ & $62.1 \%(41)$ & $59.6 \%(81)$ & $51.7 \%(449)$ \\
Negative Experience & $52.5 \%(254)$ & $46.4 \%(39)$ & $46.9 \%(46)$ & $37.9 \%(25)$ & $40.4 \%(55)$ & $48.3 \%(419)$
\end{tabular}

Program modality was significantly associated with students' experience with online education $(\mathrm{p}<0.001)$. Students in entirely online programs had more positive experience with online education than those who were in a partially online program.

\section{Discussion}

This study, based on a large data set, corresponds to the findings of earlier studies and provides additional insights into the online student learning experience. Based on the study's snapshot of online MLIS students it suggests many would be considered non-traditional students, predominately White women in their mid-30s, living in urban areas, who prefer the partially online experience as their main mode of instruction rather than an entirely online program. These students tended to live closer to campus (less than 50 miles from campus) and were employed. Conversely, those who were completely online, especially those in rural areas, lived farther away from campus.

Most interesting is the dichotomy and statistically significant differences between age and program modality. Entirely online students tended to be older while younger students tended to prefer the partially online experience. This supports Tucker (2001) and Dutton et al.'s (2002) findings that older students were more likely to prefer distance education because of family and work commitments. 
Exploratory factor analysis revealed three primary motivation factors for students who were enrolled in partially online programs: accommodation, predisposition, and selectivity. Students reported that accommodation was an essential factor because of limitations in their time and schedules, which made pursuing an MLIS degree possible. This finding was consistent with previous studies (Dutton et al., 2002; Dyrbye et al., 2009; Mellon \& Kester, 2004; Pastore \& Carr-Chellman, 2009; Scott, 2011; Wyatt, 2005) that suggest that minimal disruption to the student's life (e.g., having to relocate, quitting job, and long commute) is an essential factor in pursuing online education. More specifically, there was significant association of age (i.e., older students) and employment status (i.e., full-time employed students) with accommodation, which motivated a student to choose online courses. This result supported Dutton et al. (2002) and Tucker's (2001) findings that older students often chose online courses to avoid long commutes and potential conflicts with work and family responsibilities. Students who lived in rural areas also significantly valued accommodation more than those in urban areas because of their lack of access to educational opportunities, as well as the longer commute times they would face, if attending traditional campus-based courses as noted by Mellon and Kester (2004).

Predisposition was a second factor identified through exploratory factor analysis. This suggests that, even if there were no prevailing barriers to taking a face-to-face course on campus, students still preferred taking online classes. These students were often curious about online education and wanted to give it a try, were recommended by others to take an online class, under the impression 
that online classes might be easier, or had taken an online class before and had a positive experience. However, both Scott (2011) and Pastore and Carr-Chellman (2009) reported that these influences had little impact on student motivation to choose online coursework. Students who had full-time or part-time employment rated predisposition significantly more important than those unemployed.

Students who had some type of work-related commitment were probably more inclined to enroll in online classes as they perceive online classes may allow them to graduate sooner or be easier than taking a face-to-face class.

Selectivity of online courses was found to be the third factor with some impact on the student's decision to choose an online course. The top rated statement was, "The same class was not available in face-to-face format," followed by "Broader selection of classes available online." In essence, the selectivity factor informs the students' need for accommodation in having access to an online course. Not being able to enroll in a face-to-face class was rated much higher in Pastore and Carr-Chellman's (2009) study than predisposition as an important motivating factor for students who chose online coursework. The discrepancy may be, in part, attributed to the limited scope of their research, which only studied students from a single institution.

Overall, entirely online MLIS students were satisfied with typical student services provided including virtual practica, online lectures, professional development, and social networking opportunities. However, they seemed to be less satisfied, although still within the satisfied range, with career planning opportunities, placement services, academic advising, and mentoring. This 
suggests that accredited MLIS programs are doing a good job in some areas but have opportunities to improve in advising, mentoring, and career-oriented services, all of which are potentially more challenging to deliver virtually to online students.

Results show a number of significant associations among demographic variables (i.e., age, employment status, commute distance, and metro status), student experience, and course modality. Interestingly enough, students reported that they felt supported in terms of IT and academic support but faced their greatest challenges with isolation from both peers and instructors (Croft et al., 2010; Hara, 2000; Kazmer, 2007; Muilenburg \& Berge, 2005). The results also suggest that younger students (Generation Y) and those who worked part-time had significantly more negative perceptions of online education than their older peers and those who worked full-time. This finding suggests that those who are younger and are not working as much may have higher expectations and an increased desire for social connection to both their peers and instructors (Kazmer et al., 2013). In contrast, older students with presumably more established social networks and likely working full-time, may have had less time or desire for this type of collaboration and socialization (Dutton et al., 2002; Fredericksen et al., 1999). In addition, older students tended not to perceive such issues as important barriers in online education as their younger peers (Hagel \& Shaw, 2006).

Those who live both in rural areas and further away from campus had more positive perceptions of online education. This difference may be attributed to the satisfaction remote learners had for having access to an education, as well 
as with the value-added convenience factors of saving money and time by not having to make long commutes to campus. On the other hand, students from urban areas who lived closer to main campus did not perceive such benefits as positively. They probably still had the expectation of having more face-to-face contact with their programs.

Program modality, whether participation was in an entirely online versus in a partially online program, also had a statistically significant difference in student perceptions. Those who were in entirely online programs had more positive perceptions than those who were in partially online programs. This finding suggests that entirely online programs, which students understand only offer instruction in a single modality, provide consistency and homogeneity of experience that students appear to expect and value. Partially online programs and courses, however, provide students with a diversity of instructional and learning environments, often even merging online and campus-based students together, and these options or variability present many opportunities for confusion that can negatively impact students' experiences.

\section{Implications \& Future Research}

This study enhances our understanding of online MLIS students and their experiences. As some MLIS programs have increased their online offerings over the years while others have been entirely online for many years, the findings from this study have implications for these programs to refine delivery and services to online MLIS students. The study's implications are in four areas: 1) outreach, 
marketing, and recruitment, 2) programming, 3) academic and career support, and 4) socialization.

First, by gaining a better demographic understanding of MLIS students taking online courses, there is an opportunity to enhance a program's outreach, marketing, and recruitment efforts. The bi-national findings offered by this study serves as baseline data and a potential point of comparison. Compiling demographic data on an ongoing basis to identify whom is studying online and revealing who is not, allows programs to continue to recruit from the same population and/or to reach out to under-represented groups. Markets can be targeted and effective strategies can be developed, including communication messages and channels that need to be rethought and made appropriate to their selected markets.

Second, the preferences of MLIS students taking online classes differed at statistically significant levels on five variables: age (generational cohort), employment status, metro status, commute distance, and program modality. Programs should consider gathering experiential data across these five variables in order to better customize and develop learning environments that are more student-driven and effective. For example, accommodation was found to be associated with age and employment status at statistically significant levels for partially online students. When examining their own experiential data, areas that programs can customize may include delivery, scheduling, quality, and cost. Other areas such as content, pedagogy, and assessment bear closer examination by programs or by future research. These areas have the potential to impact 
student learning and engagement while the former areas relate to access to LIS education.

Third, online MLIS students were generally satisfied with the suite of student services they received, but there are implications for enhancing academic and career support. Prior studies revealed four program areas to improve, and this study further concurs: career planning opportunities, placement services, academic advising, and mentoring have room for improvement (e.g., Haythornthwaite, Kazmer, Robins, \& Shoemaker, 2000; Kazmer, 2007). Technology is available that enhance access (e.g., live streaming, recording, and hosting recordings/materials) to events, and engagement between on-campus and off-campus students, or among online students only. Advising is only limited by the availability of staff and/or faculty as flexibility of advising schedules is within the control of a program's administration. Career planning can be coordinated, and social media engaged, to involve faculty and professionals (e.g., alumni, potential employers) with students, as a departure from students typically engaging with either faculty or professionals.

Lastly, the opportunity to develop relationships (i.e., a sense of community) and professionally (i.e., one's identity and knowledge) was noted by the study's participants. This has implications for online MLIS programs, which can pay attention to increased opportunities for socialization. More specifically, there are four prevalent concerns raised by students in online learning: a sense of isolation from their instructors, a sense of isolation from their peers, a lack of access to professional events on campus, and a lack of access to networking 
opportunities with peers. Prior studies also provide the impetus for the reassessment of content delivery and instruction techniques, (e.g., Rovai, 2003) and the offering of enrichment activities with peers and professionals (e.g., Glomb, Midenhall, Mason, \& Salzberg, 2009; Luo, 2010). Again, as noted earlier, the deployment of information and communication technologies, the engagement of social media, and the re-commitment to the needs of online education by applying a schedule for faculty and staff to cover a $24 / 7$ schedule and a suite of professional development opportunities are needed. By providing the tools and opportunities for the development of virtual learning communities, not just online teaching classrooms, and by requiring students to develop an online professional learning network, a program can learn the professional interests and needs of their students that they can attempt to accommodate.

The study has provided an important baseline from which further research can be conducted to extend the scope and engage more methodologies. Future research includes reaching out to faculty based on these findings to build a similar framework for faculty perceptions and satisfaction in delivering online instruction. A similar study in scope using qualitative methods would infuse a deeper understanding of the quantitative findings uncovered by this study. Furthermore, this study could be repeated nationally to include non-accredited MLIS program and internationally using comparative methods to include undergraduate and graduate programs. 


\section{References}

8 countries leading the way in online education. (2012, June 28). Retrieved June 25, 2015, from http://monitor.icef.com/2012/06/8-countries-leading-the-way-inonline-education/

Alphabetical List of Institutions with ALA-Accredited Programs (2013). Retrieved April 16, 2012, from http://www.ala.org/accreditedprograms/directory/alphalist

Allen, E. I., \& Seaman, J. (2007). Online nation: Five years of growth in online learning. Needham, MA: Sloan Consortium.

Allen, E. I., \& Seaman, J. (2010). Class differences: Online education in the United States, 2010. Needham, MA: Sloan Consortium.

Barron, D. D. (1996). Distance education in North American library and information science education: Applications of technology and commitment. Journal of the American Society for Information Science, 47(11), 805-810. doi:

10.1002/(SICI)1097-4571(199611)47:11

Bird, N. J., Chu, C. M., \& Oguz, F. (2011). Four "I"s of internships for the new information society: Intentional, interconnected, interdisciplinary and international. Presented at the 77th IFLA General Conference and Assembly, San Juan, Puerto Rico. Retrieved from http://conference.ifla.org/past-wlic/2011/120bird-en.pdf

Croft, N., Dalton, A., \& Grant, M. (2010). Overcoming isolation in distance learning: Building a learning community through time and space. Journal for Education in the Built Environment, 5(1), 27-64.

Daniel, E. H., \& Saye, J. D. (2002). ALISE Library and Information Science Education Statistical Report 2002. Chicago, IL: Association for Library and Information Science Education. 
Daniel, E. H., \& Saye, J. D. (2003). ALISE Library and Information Science Education Statistical Report 2003. Chicago, IL: Association for Library and Information Science Education.

Daniel, E. H., \& Saye, J. D. (2005). ALISE Library and Information Science Education Statistical Report 2004. Chicago, IL: Association for Library and Information Science Education.

Dutton, J., Dutton, M., \& Perry, J. (2002). How do online students differ from lecture students? Journal of Asynchronous Learning Networks, 6(1).

Dyrbye, L., Cumyn, A., Day, H., \& Heflin, M. (2009). A qualitative study of physicians' experiences with online learning in a masters degree program: Benefits, challenges, and proposed solutions. Medical Teacher, 31(2), e40-e46. doi: $10.1080 / 01421590802366129$

Field, A. (2013). Discovering Statistics Using SPSS ( $4^{\text {th }}$ ed). Thousand Oaks: SAGE Publications.

Fredericksen, E., Swan, K., Pelz, W., Pickett, A., \& Shea, P. (1999). Student satisfaction and perceived learning with online courses: Principles and examples from the SUNY Learning Network. In Proceedings of the ALN Summer Workshop. Retrieved from http://hdl.handle.net/1802/2582

Glomb, N., Midenhall, T., Mason, L. L., \& Salzberg, C. (2009). Reducing isolation through regional mentors and learning communities: A way to support rural learners. Rural Special Education Quarterly, 28(4), 31-35.

Hagel, P., \& Shaw, R. N. (2006). Students' perceptions of study modes. Distance Education, 27(3), 283-302. doi: 10.1080/01587910600940398

Hanover Research. (2011). Trends in Global Distance Learning. Washington, DC.

Retrieved from http://www.hanoverresearch.com/wpcontent/uploads/2011/12/Trends-in-Global-Distance-Learning-Membership.pdf 
Hara, N. (2000). Student distress in a Web-based distance education course. Information, Communication \& Society, 3(4), 557-579. doi:10.1080/13691180010002297

Hara, N., \& Kling, R. (1999). Students' frustrations with a Web-based distance education course. First Monday, 4(12). doi:10.5210/fm.v4i12.710

Haythornthwaite, C., Kazmer, M. M., Robins, J., \& Shoemaker, S. (2000). Community development among distance learners: Temporal and technological dimensions. Journal of Computer-Mediated Communication, 6(1). doi: 10.1111/j.10836101.2000.tb00114.x

IBIS Capital. (2013). Global e-learning investment review. Retrieved from http://www.smarthighered.com/wp-content/uploads/2013/02/IBIS-Capital-eLearning-Lessons-for-the-Future.pdf

Islam, M. S., Kunifuji, S., Hayama, T., \& Miura, M. (2011). Towards exploring a global scenario of e-learning in library and information science schools. The International Information \& Library Review, 43(1), 15-22. doi:

10.1016/j.iilr.2011.01.004

Kazmer, M. M. (2007). How do student experiences differ in online LIS programs with and without a residency? The Library Quarterly, 77(4), 359-383.

Kazmer, M. M., Gibson, A. N., \& Shannon, K. (2013). Perceptions and experiences of elearning among on-campus students. In A. Sigal (Ed.), Advancing Library Education: Technological Innovation and Instructional Design. IGI Global. doi: 10.4018/978-1-4666-3688-0.ch004

Luo, L. (2010). Social networking websites: An exploratory study of student peer socializing in an online LIS program. Journal of Education for Library and Information Science, 51(2), 86-102.

Means, B., Toyama, Y., Murphy, R., Bakia, M., \& Jones, K. (2009). Evaluation of evidence-based practices in online learning: A meta-analysis and review of 
online learning studies. Report prepared for the U.S. Department of Education, Office of Planning, Evaluation, and Policy Development, Washington, D.C.

Mellon, C. A., \& Kester, D. D. (2004). Online library education programs: Implications for rural students. Journal of Education for Library and Information Science, 45(3), 210-220. doi: $0.2307 / 40323888$

Mortagy, Y., \& Boghikian-Whitby, S. (2010). A longitudinal comparative study of student perceptions in online education. Interdisciplinary Journal of E-Learning and Learning Objects, 6(1), 23-44.

Muilenburg, L. Y., \& Berge, Z. L. (2005). Student barriers to online learning: A factor analytic study. Distance Education, 26(1), 29-48. doi:

$10.1080 / 08923640109527081$

Pastore, R., \& Carr-Chellman, A. (2009). Motivations for residential students to participate in online courses. Quarterly Review of Distance Education, 10(3), 263-277.

Rovai, A. P. (2003). The relationships of communicator style, personality-based learning style, and classroom community among online graduate students. The Internet and Higher Education, 6(4), 347-363.

Rural-Urban Commuting Area Codes. (n.d.). Retrieved July 12, 2012, from http://depts.washington.edu/uwruca/ruca-maps.php

Saye, J. D. (2008). ALISE Library and Information Science Education Statistical Report 2005. Chicago, IL: Association for Library and Information Science Education.

Saye, J. D., \& Wallace, D. P. (2009). ALISE Library and Information Science Education Statistical Report 2006. Chicago, IL: Association for Library and Information Science Education. 
Scott, J. (2011). Distance education report. California Community Colleges Chancellor's Office. Retrieved from http://extranet.cccco.edu/Portals/1/AA/DE/FinalDE2011Report.pdf

Sher, A. (2009). Assessing the relationship of student-instructor and student-student interaction to student learning and satisfaction in Web-based online learning environment. Journal of Interactive Online Learning, 8(2), 102-120.

Small, R. V., \& Paling, S. (2002). The evolution of a distance learning program in library and information science: A follow-up study. Journal of Education for Library and Information Science, 43(1), 47-61.

Tucker, S. (2001). Distance education: Better, worse, or as good as traditional education? Online Journal of Distance Learning Administration, 4(4).

Wallace, D. P. (2012). ALISE Library and Information Science Education Statistical Report 2012. Chicago, IL: Association for Library and Information Science Education.

Wallace, D. P., \& Naidoo, J. (2010a). ALISE Library and Information Science Education Statistical Report 2009. Chicago, IL: Association for Library and Information Science Education.

Wallace, D. P., \& Naidoo, J. (2010b). ALISE Library and Information Science Education Statistical Report 2010. Chicago, IL: Association for Library and Information Science Education.

Wilde, M. L., \& Epperson, A. (2006). A survey of alumni of LIS distance education programs: Experiences and implications. The Journal of Academic Librarianship, $32(3), 238-250$.

Wyatt, G. (2005). Satisfaction, academic rigor and interaction: Perceptions of online instruction. Education, 125(3), 460. 
Yuan, L., \& Powell, S. (2013). MOOCs and open education: implications for higher education. Bolton: University of Bolton, Centre for Educational Technology, Interoperability and Standards \& JISC. 


\section{Appendix A: Online Learning - LIS Student Survey}

Q1 (Informed Consent) Do you agree to the consent information provided above and wish to participate in the study?

Y Yes, I agree to participate (1)

No, I do not agree to participate (2)

If No, I do not agree to participate Is Selected, Then Skip To End of Survey

Q2 An online class is defined as a Web-based instructional method in which at least $80 \%$ of the instruction occurs regardless of the content delivery method over the Internet.

Have you taken an online class in an ALA accredited MLIS/MLS/M.S. program?

Yes (1)

○ No (2)

If No Is Selected, Then Skip To End of Survey

Q3 Part I: Demographic Information

Which LIS/IS graduate school program do you currently attend?

$<$ Drop Down List of LIS Programs $>$

Q4 What is your gender?

O Male (1)

Female (2)

O Other (3) 
Q5 What is your race and/or ethnicity?

American Indian or Native Alaskan (1)

Asian, Asian-American, or Pacific Islander (2)

White (non-Hispanic) (3)

O Black or African-American (4)

Hispanic or Latino (5)

O Multiracial (6)

Other, please specify (7)

Q6 Please enter your residential zip code while you were in the MLIS/MLS/M.S. program.

Q7 What is your age?

Q8 What is your cumulative GPA? (If not on a 4.0 scale, please specify scale.)

Q9 What is your current employment status?

Employed full-time (1)

Employed part-time (2)

Unemployed (3)

Other, please explain (4)

Q10 Number of credit hours completed (not including current semester) in MLIS/MLS/M.S.

program

Q11 Part II: Online Classes Overall, what percentage of classes have you taken online?

O less than $25 \%(1)$

O $25 \%-49 \%(2)$

O $50 \%-74 \%(3)$

O $75 \%-99 \%(4)$

O $100 \%(5)$ 
Q12 Are you currently enrolled in an entirely online MLIS program?

○ Yes (1)

○ No (2)

If No Is Selected, Then Skip To Question 15 
Q13 How important were these factors for your choice of online MLIS/MLS/M.S. program?

[Entirely Online Only]

\begin{tabular}{|c|c|c|c|c|c|c|}
\hline & $\begin{array}{c}\text { Not at } \\
\text { all } \\
\text { Importan } \\
\mathrm{t}(1)\end{array}$ & $\begin{array}{c}\text { Very } \\
\text { Unimporta } \\
\text { nt (2) }\end{array}$ & $\begin{array}{c}\text { Neither } \\
\text { Important } \\
\text { nor } \\
\text { Unimporta } \\
\text { nt (3) }\end{array}$ & $\begin{array}{c}\text { Very } \\
\text { Importan } \\
\text { t (4) }\end{array}$ & $\begin{array}{l}\text { Extremel } \\
\qquad y \\
\text { Importan } \\
t(5)\end{array}$ & $\begin{array}{c}\text { Not } \\
\text { Applicabl } \\
\text { e (0) }\end{array}$ \\
\hline $\begin{array}{l}\text { Quality of } \\
\text { education (1) } \\
\text { No need to } \\
\text { relocate (2) }\end{array}$ & 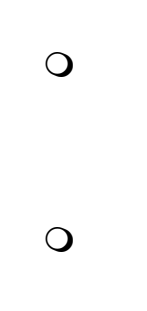 & $O$ & 0 & 0 & 0 & 0 \\
\hline $\begin{array}{l}\text { No need to } \\
\text { change/quit } \\
\text { current job (3) }\end{array}$ & O & 0 & 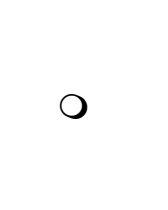 & 0 & 0 & 0 \\
\hline $\begin{array}{l}\text { Cost of } \\
\text { education (4) }\end{array}$ & O & 0 & 0 & 0 & 0 & 0 \\
\hline $\begin{array}{l}\text { No onsite (face- } \\
\text { to-face) } \\
\text { MLIS/MLS/M. } \\
\text { S. program } \\
\text { available in my } \\
\text { area (5) }\end{array}$ & $\mathrm{O}$ & 0 & $\mathrm{O}$ & 0 & 0 & 0 \\
\hline
\end{tabular}

Q14 How satisfied are you with availability of the following elements of your online MLIS/MLS/M.S. program? [Entirely Online Only] 


\begin{tabular}{|c|c|c|c|c|c|c|}
\hline & $\begin{array}{c}\text { Very } \\
\text { Dissatisfied } \\
\text { (2) }\end{array}$ & $\begin{array}{c}\text { Dissatisfied } \\
\text { (3) }\end{array}$ & $\begin{array}{c}\text { Neutral } \\
(4)\end{array}$ & $\begin{array}{c}\text { Satisfied } \\
\text { (5) }\end{array}$ & $\begin{array}{c}\text { Very } \\
\text { Satisfied } \\
(6)\end{array}$ & $\begin{array}{c}\text { Not } \\
\text { Available } \\
\text { (7) }\end{array}$ \\
\hline $\begin{array}{c}\text { Career } \\
\text { planning (1) }\end{array}$ & 0 & $\mathrm{O}$ & 0 & 0 & 0 & 0 \\
\hline $\begin{array}{l}\text { Professional } \\
\text { development } \\
\text { (2) }\end{array}$ & 0 & 0 & 0 & 0 & 0 & 0 \\
\hline $\begin{array}{l}\text { Placement } \\
\text { services (3) }\end{array}$ & 0 & 0 & 0 & $\mathrm{O}$ & 0 & 0 \\
\hline $\begin{array}{c}\text { Social } \\
\text { networking } \\
\text { (4) }\end{array}$ & 0 & 0 & O & O & 0 & 0 \\
\hline $\begin{array}{c}\text { Virtual } \\
\text { practica (5) }\end{array}$ & 0 & 0 & 0 & 0 & 0 & 0 \\
\hline $\begin{array}{c}\text { Lectures/talks } \\
\text { (outside of } \\
\text { class) (6) }\end{array}$ & 0 & 0 & 0 & 0 & 0 & 0 \\
\hline $\begin{array}{c}\text { Mentoring } \\
\text { (e.g. peer, } \\
\text { professional) } \\
\text { (7) }\end{array}$ & 0 & 0 & 0 & 0 & 0 & 0 \\
\hline $\begin{array}{l}\text { Academic } \\
\text { advising (8) }\end{array}$ & 0 & 0 & 0 & 0 & 0 & 0 \\
\hline
\end{tabular}


Q15 To what degree do you agree with these statements with regard to your choice of online MLIS/MLS/M.S. classes? [Partially Online Only] 


\begin{tabular}{|c|c|c|c|c|c|}
\hline & $\begin{array}{c}\text { Strongly } \\
\text { Disagree (1) }\end{array}$ & Disagree (2) & $\begin{array}{c}\text { Neither } \\
\text { Agree nor } \\
\text { Disagree (3) }\end{array}$ & Agree (4) & $\begin{array}{l}\text { Strongly } \\
\text { Agree (5) }\end{array}$ \\
\hline $\begin{array}{l}\text { An online class } \\
\text { lets me } \\
\text { graduate } \\
\text { sooner (1) }\end{array}$ & 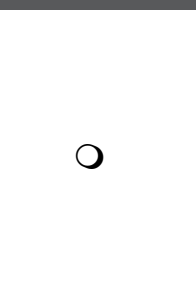 & $\mathrm{O}$ & O & O & 0 \\
\hline $\begin{array}{l}\text { Personal } \\
\text { circumstances } \\
\text { (e.g., family, } \\
\text { health, } \\
\text { pregnancy) } \\
\text { required me to } \\
\text { take online } \\
\text { classes. (2) }\end{array}$ & 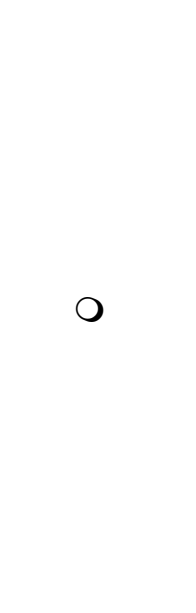 & $\mathrm{O}$ & 0 & O & 0 \\
\hline $\begin{array}{c}\text { The same class } \\
\text { was not }\end{array}$ & & & & & \\
\hline $\begin{array}{l}\text { available in } \\
\text { face-to-face } \\
\text { format (3) }\end{array}$ & O & 0 & O & O & O \\
\hline $\begin{array}{l}\text { I had a good } \\
\text { experience } \\
\text { with an online } \\
\text { class before (4) }\end{array}$ & 0 & 0 & 0 & 0 & O \\
\hline
\end{tabular}




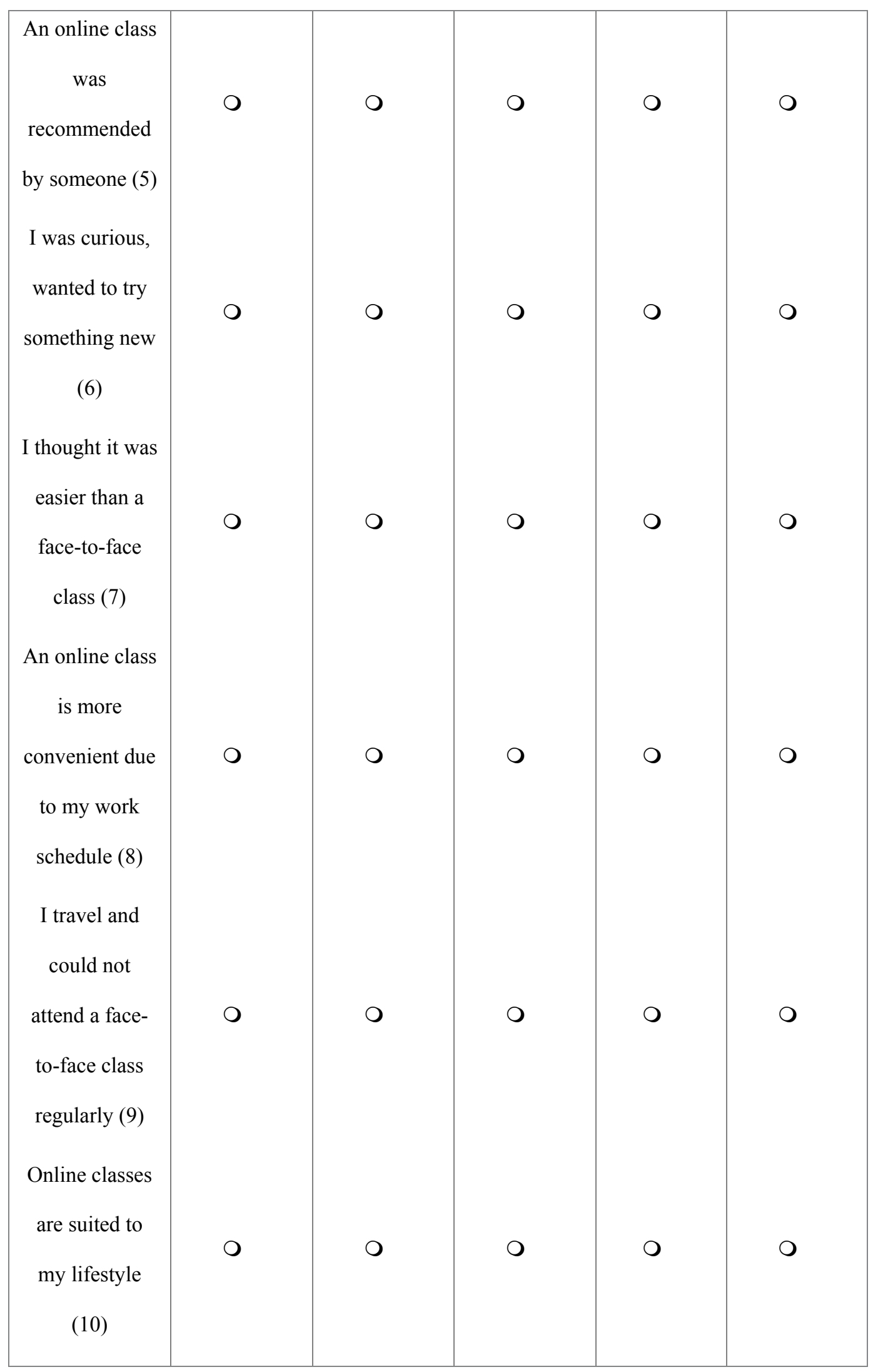




\begin{tabular}{|c|c|c|c|c|c|}
\hline $\begin{array}{l}\text { Broader } \\
\text { selection of }\end{array}$ & & & & \\
classes & 0 & 0 & 0 & 0 & 0 \\
available & & & & \\
online (11) & & & & \\
\hline
\end{tabular}

Q16 How often do you experience the following issues when taking online MLIS classes? 


\begin{tabular}{|c|c|c|c|c|c|}
\hline & Never (1) & Rarely (2) & Sometimes (3) & Often (4) & Always (5) \\
\hline $\begin{array}{c}\text { Sense of } \\
\text { isolation from } \\
\text { peers (1) }\end{array}$ & $\mathrm{O}$ & O & 0 & $\mathrm{O}$ & $\mathrm{O}$ \\
\hline $\begin{array}{l}\text { Sense of } \\
\text { isolation from } \\
\text { instructor (2) }\end{array}$ & $\mathrm{O}$ & O & O & $\mathrm{O}$ & $\mathrm{O}$ \\
\hline $\begin{array}{l}\text { Lack of } \\
\text { technical } \\
\text { support (3) }\end{array}$ & $\mathrm{O}$ & O & $\mathrm{O}$ & $\mathrm{O}$ & $\mathrm{O}$ \\
\hline $\begin{array}{l}\text { Lack of } \\
\text { academic } \\
\text { support (4) }\end{array}$ & $\mathrm{O}$ & O & 0 & O & $\mathrm{O}$ \\
\hline $\begin{array}{c}\text { Lack of } \\
\text { networking } \\
\text { opportunities } \\
\text { with peers (5) }\end{array}$ & $\mathrm{O}$ & $\mathrm{O}$ & $\mathrm{O}$ & $\mathrm{O}$ & $\mathrm{O}$ \\
\hline $\begin{array}{c}\text { Lack of } \\
\text { professional } \\
\text { development } \\
\text { opportunities } \\
\text { (6) }\end{array}$ & $\mathrm{O}$ & 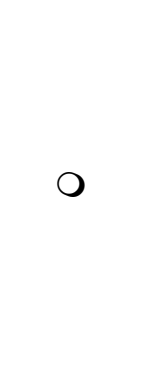 & O & O & $\mathrm{O}$ \\
\hline $\begin{array}{l}\text { Lack of access } \\
\text { to professional } \\
\text { events on } \\
\text { campus (7) }\end{array}$ & $\mathrm{O}$ & $\mathrm{O}$ & O & $\mathrm{O}$ & $\mathrm{O}$ \\
\hline
\end{tabular}


Q17 Which class setting do you prefer for each of these class types?

\begin{tabular}{|c|c|c|c|c|}
\hline & Online & Online with & Blended & \\
& completely & synchronous & (Online and & Face-to-face \\
& asynchronous (1) & components (2) & Face-to-face) & $(4)$ \\
\hline Foundations of & 0 & 0 & 0 & 0 \\
the Profession (1) & 0 & 0 & 0 & 0 \\
Reference (2) & 0 & 0 & 0 & 0 \\
Cataloging (3) & 0 & 0 & 0 & 0 \\
Research & 0 & 0 & 0 \\
Methods (4) & 0 & 0 & 0 \\
Management (5) & & 0 & 0 \\
\hline
\end{tabular}

Q18 What other comments do you have to share regarding your experiences with online MLIS/MLS/M.S. education? 